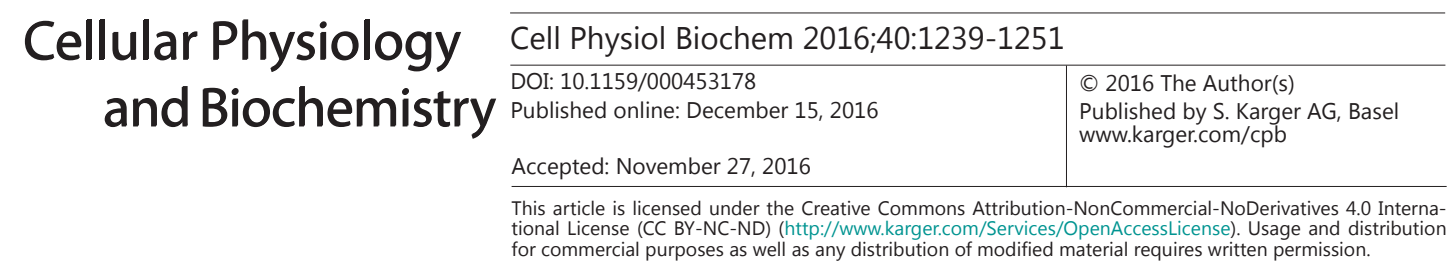

\title{
Triggering of Suicidal Erythrocyte Death by Bexarotene
}

\author{
Abdulla Al Mamun Bhuyana Rosi Bissinger ${ }^{a}$ Hang Cao ${ }^{a}$ Florian Langa,b \\ aDepartments of Cardiology, Vascular Medicine and Physiology, Eberhard-Karls-University of \\ Tuebingen, Tuebingen, Germany; ${ }^{b}$ Department of Molecular Medicine II, Medical Faculty, Heinrich \\ Heine University, Duesseldorf, Duesseldorf, Germany
}

\section{Key Words}

Phosphatidylserine $\cdot$ Eryptosis $・$ D4476 $•$ Casein kinase $・$ Oxidative stress $•$ Calcium

\begin{abstract}
Background/Aims: The retinoid $\mathrm{X}$ receptor agonist bexarotene is utilized for the treatment of cutaneous T-cell lymphoma and is effective in several further malignancies. The substance counteracts tumor growth in part by triggering suicidal death or apoptosis of tumor cells. Side effects of bexarotene treatment include anemia. Theoretically, bexarotene induced anemia could be secondary to stimulation of suicidal erythrocyte death or eryptosis, characterized by cell shrinkage and cell membrane scrambling with phosphatidylserine translocation to the erythrocyte surface. Signaling potentially stimulating eryptosis include increase of cytosolic $\mathrm{Ca}^{2+}$ activity $\left(\left[\mathrm{Ca}^{2+}\right]_{\mathrm{i}}\right)$, induction of oxidative stress, increase of ceramide abundance, as well as activation of staurosporine sensitive protein kinase C, SB203580 sensitive p38 kinase, D4476 sensitive casein kinase 1 , and ZVAD sensitive caspases. The present study explored, whether bexarotene induces eryptosis and, if so, whether its effect involves $\mathrm{Ca}^{2+}$ entry, oxidative stress, ceramide, kinases and/or caspases. Methods: Flow cytometry was employed to quantify phosphatidylserine exposure at the cell surface from annexin-V-binding, cell volume from forward scatter, $\left[\mathrm{Ca}^{2+}\right]_{\mathrm{i}}$ from Fluo3-fluorescence, reactive oxygen species (ROS) abundance from DCFDA dependent fluorescence, and ceramide abundance utilizing specific antibodies. Hemolysis was estimated from hemoglobin concentration in the supernatant. Results: A 48 hours exposure of human erythrocytes to bexarotene $(\geq 0.4 \mu \mathrm{g} / \mathrm{ml})$ significantly increased the percentage of annexin-V-binding cells without significantly modifying forward scatter. Bexarotene significantly increased Fluo3-fluorescence and DCFDA fluorescence. Bexarotene tended to increase ceramide abundance, an effect, however, not reaching statistical significance. The effect of bexarotene on annexin-V-binding was significantly blunted by removal of extracellular $\mathrm{Ca}^{2+}$ and by addition of D4476 $(10 \mu \mathrm{M})$, but not by addition of staurosporine $(1 \mu \mathrm{M})$, SB203580 $(2 \mu \mathrm{M})$, or zVAD $(10 \mu \mathrm{M})$. Conclusions: Bexarotene triggers phospholipid scrambling of the erythrocyte cell membrane, an effect at least in part due to $\mathrm{Ca}^{2+}$ entry, oxidative stress, and activation of D4476 sensitive casein kinase.




\section{Cellular Physiology Cell Physiol Biochem 2016;40:1239-1251 \begin{tabular}{l|l|l} 
and Biochemistry & $\begin{array}{l}\text { DOI: 10.1159/000453178 } \\
\text { Published online: December 15, } 2016\end{array}$ & $\begin{array}{l}\text { (c) } 2016 \text { The Author(s). Published by S. Karger AG, Basel } \\
\text { www.karger.com/cpb }\end{array}$
\end{tabular} \\ Bhuyan et al.: Bexarotene-Induced Eryptosis}

\section{Introduction}

Bexarotene, a synthetic analog (4-[1-(3,5,5,8,8-pentamethyl-5,6,7,8-tetrahydro-2naphthyl)ethynyl]benzoic acid) of retinoids [1,2], selectively binds to and activates the retinoid X receptor (RXRs) subfamilies [1-8], thus inhibiting tumor growth both, in vitro and in vivo [1]. The substance is used for the treatment of cutaneous T-cell lymphoma (CTCL) $[3,5,6,8-28]$, and has been shown to be effective in other malignancies, such as non-small cell lung cancer [16, 29, 30], breast cancer [16, 31-33], and - in animals - colon cancer [34], breast cancer $[35,36]$ and lung cancer [37]. However, bexarotene treatment may trigger extracutaneous lymphoma [38]. Moreover, bexarotene has been used in psoriasis [39].

In the brain, bexarotene has been shown to provide neuroprotection in traumatic brain injury [40] by inhibiting neuronal apoptosis, an effect requiring Apo protein E [40]. Along those lines, bexarotene has been shown to reverse neurodegeneration, improve cognition, and decrease the levels of amyloid- $\beta$ in transgenic mice expressing familial Alzheimer disease mutations [41].

Bexarotene is at least in part effective by blocking cell cycle progression [4, 42], inducing apoptosis [4-6, 8, 24, 27, 28, 34, 35, 37, 43-48], fostering differentiation [4, 35, 39], preventing multidrug resistance $[4,33]$, inhibiting angiogenesis [4], and counteracting metastasis [4]. Signaling triggered by bexarotene includes ceramide formation [31], activation of the p53/ p73 pathway [42], and mitochondrial release of cytochrome C [48].

Common side effects of systemic bexarotene treatment include hyperlipidemia $[6,14$, $16,17,49]$, hypothyroidism [6, 14, 16, 20, 49], headache [6], xeroderma [16], leukopenia or neutropenia [49], nasopharyngitis [49], and anemia [49].

In view of the stimulating effect of bexarotene on suicidal death of nucleated cells [4-6, $8,24,27,28,34,35,43-48]$, the anemia could result from suicidal death of erythrocytes or eryptosis [50].

The hallmark of eryptosis is cell membrane scrambling with phosphatidylserine translocation to the cell surface [50]. The cell membrane scrambling is usually paralleled by cell shrinkage [51]. Signaling involved in the triggering of eryptosis include increase of cytosolic $\mathrm{Ca}^{2+}$ activity $\left(\left[\mathrm{Ca}^{2+}\right]_{\mathrm{i}}\right)[50]$, ceramide [52], caspases [50, 53, 54], stimulated activity of casein kinase $1 \alpha$, Janus-activated kinase JAK3, protein kinase C, p38 kinase and PAK2 kinase [50], as well as impaired activity of AMP activated kinase AMPK, cGMP-dependent protein kinase, and sorafenib/sunitinib sensitive kinases [50]. Stimulators of eryptosis include hyperosmotic shock [50], oxidative stress [50], energy depletion [50], or exposure to a wide variety of xenobiotics [50,55-99]. Enhanced eryptosis is observed in a variety of clinical conditions including dehydration [100], hyperphosphatemia [101], chronic kidney disease (CKD) [102-105], hemolytic-uremic syndrome [106], diabetes [107], hepatic failure [56], malignancy [50], sepsis [108], sickle-cell disease [50], beta-thalassemia [50], Hb-C and G6PD-deficiency [50], as well as Wilsons disease [109].

The present study explored, whether bexarotene is able to trigger eryptosis. To this end, human erythrocytes from healthy volunteers were exposed to bexarotene and phosphatidylserine surface abundance, cell volume, $\left[\mathrm{Ca}^{2+}\right]_{i^{\prime}}$ ROS formation, and ceramide abundance determined by flow cytometry.

\section{Materials and Methods}

\section{Erythrocytes, solutions and chemicals}

Fresh Li-Heparin-anticoagulated blood samples were kindly provided by the blood bank of the University of Tübingen. The study is approved by the ethics committee of the University of Tübingen (184/2003 V). The blood was centrifuged at $120 \mathrm{~g}$ for $20 \mathrm{~min}$ at $21^{\circ} \mathrm{C}$ and the platelets and leukocytes-containing supernatant was disposed. Erythrocytes were incubated in vitro at a hematocrit of $0.4 \%$ in Ringer solution containing (in $\mathrm{mM}$ ) $125 \mathrm{NaCl}, 5 \mathrm{KCl}, 1 \mathrm{MgSO}_{4}, 32 \mathrm{~N}$-2-hydroxyethylpiperazine-N-2-ethanesulfonic acid (HEPES; pH 7.4), 5 glucose, 1 $\mathrm{CaCl}_{2}$, at $37^{\circ} \mathrm{C}$ for 48 hours. Where indicated, erythrocytes were exposed for 48 hours to bexarotene (MedChem 


\section{Cellular Physiology Cell Physiol Biochem 2016;40:1239-1251 \begin{tabular}{l|l|l} 
and Biochemistry & DoI: 10.1159/000453178 & $\begin{array}{l}\text { C } 2016 \text { The Author(s). Published by S. Karger AG, Basel } \\
\text { www.karger.com/cpb }\end{array}$
\end{tabular} \\ Bhuyan et al.: Bexarotene-Induced Eryptosis}

Express, Princeton, USA). In order to estimate the impact of $\mathrm{Ca}^{2+}$ entry on bexarotene induced eryptosis, erythrocytes were exposed to bexarotene in the absence of extracellular $\mathrm{Ca}^{2+}$ and presence of $\mathrm{Ca}^{2+}$ chelator EGTA (1 mM, Merck Millipore, Darmstadt, Germany). To test for an involvement of kinases, erythrocytes were exposed for 48 hours to a combination of bexarotene and p38 kinase inhibitor SB203580 (Tocris bioscience, Bristol, UK), protein kinase C inhibitor staurosporine (Enzo Life Sciences, Lörrach, Germany) or casein kinase inhibitor D4476 (Tocris Bioscience, Bristol, UK). The impact of caspases was elucidated utilizing the pancaspase inhibitor zVAD (Enzo Life Sciences, Lörrach, Germany).

\section{Annexin-V-binding and forward scatter}

After incubation under the respective experimental condition, a $150 \mu \mathrm{l}$ cell suspension was washed in Ringer solution containing $5 \mathrm{mM} \mathrm{CaCl}_{2}$ and then stained with Annexin-V-FITC (1:200 dilution; ImmunoTools, Friesoythe, Germany) in this solution at $37^{\circ} \mathrm{C}$ for $15 \mathrm{~min}$ under protection from light. The annexin-Vabundance at the erythrocyte surface was subsequently determined on a FACS Calibur (BD, Heidelberg, Germany). Annexin-V-binding was measured with an excitation wavelength of $488 \mathrm{~nm}$ and an emission wavelength of $530 \mathrm{~nm}$. A marker (M1) was placed to set an arbitrary threshold between annexin-V-binding cells and control cells. The same threshold was used for untreated and bexarotene treated erythrocytes. A dot plot of forward scatter (FSC) vs. side scatter (SSC) was set to linear scale for both parameters. The threshold of forward scatter was set at the default value of " 52 ".

\section{Intracellular $\mathrm{Ca}^{2+}$}

After incubation, erythrocytes were washed in Ringer solution and loaded with Fluo-3/AM (Biotium, Hayward, USA) in Ringer solution containing $5 \mathrm{mM} \mathrm{CaCl}_{2}$ and $5 \mu$ M Fluo-3/AM. The cells were incubated at $37^{\circ} \mathrm{C}$ for $30 \mathrm{~min} . \mathrm{Ca}^{2+}$-dependent fluorescence intensity was measured with an excitation wavelength of $488 \mathrm{~nm}$ and an emission wavelength of $530 \mathrm{~nm}$ on a FACS Calibur. Afterwards, the geomean of the $\mathrm{Ca}^{2+}$ dependent fluorescence was determined.

\section{Reactive oxidant species (ROS)}

Oxidative stress was determined utilizing 2',7'-dichlorodihydrofluorescein diacetate (DCFDA). After incubation, a $150 \mu$ l suspension of erythrocytes was washed in Ringer solution and stained with DCFDA (Sigma, Schnelldorf, Germany) in Ringer solution containing DCFDA at a final concentration of $10 \mu \mathrm{M}$. Erythrocytes were incubated at $37^{\circ} \mathrm{C}$ for $30 \mathrm{~min}$ in the dark and washed two times in Ringer solution. The DCFDA-loaded erythrocytes were resuspended in $200 \mu$ l Ringer solution and ROS-dependent fluorescence intensity was measured at an excitation wavelength of $488 \mathrm{~nm}$ and an emission wavelength of $530 \mathrm{~nm}$ on a FACS Calibur (BD). Subsequently, the geomean of the DCFDA dependent fluorescence was determined.

\section{Ceramide abundance}

For the determination of ceramide, a monoclonal antibody-based assay was used. To this end, cells were stained for 1 hour at $37^{\circ} \mathrm{C}$ with $1 \mu \mathrm{g} / \mathrm{ml}$ anti ceramide antibody (clone MID 15B4, Alexis, Grünberg, Germany) in PBS containing $0.1 \%$ bovine serum albumin (BSA) at a dilution of 1:10. The samples were washed twice with PBS-BSA. The cells were stained for 30 minutes with polyclonal fluorescein isothiocyanate (FITC) conjugated goat anti-mouse IgG and IgM specific antibody (Pharmingen, Hamburg, Germany) diluted 1:50 in PBS-BSA. Unbound secondary antibody was removed by repeated washing with PBS-BSA. The samples were analyzed by flow cytometric analysis with an excitation wavelength of $488 \mathrm{~nm}$ and an emission wavelength of $530 \mathrm{~nm}$. Finally, the geomean of the ceramide-dependent fluorescence was determined.

\section{Hemolysis}

Following incubation, the erythrocyte suspension was centrifuged for $3 \mathrm{~min}$ at $1600 \mathrm{rpm}, 4^{\circ} \mathrm{C}$, and the supernatant harvested. As a measure of hemolysis, the hemoglobin $(\mathrm{Hb})$ concentration in the supernatant was determined photometrically at $405 \mathrm{~nm}$. The absorption of the supernatant of erythrocytes lysed in distilled water was defined as $100 \%$ hemolysis.

\section{Statistics}

Data are expressed as arithmetic means \pm SEM. As indicated in the figure legends, statistical analysis was made using ANOVA with Tukey's test as post-test and $t$ test as appropriate. $\mathrm{n}$ denotes the number of 
different erythrocyte specimens studied. Since different erythrocyte specimens used in distinct experiments are differently susceptible to triggers of eryptosis, the same erythrocyte specimens have been used for control and experimental conditions.

\section{Results}

The present study explored, whether bexarotene stimulates eryptosis, the suicidal erythrocyte death. The mostimportant hallmark of eryptosis is phospholipid scrambling of the cell membrane with phosphatidylserine translocation to the cell surface. Phosphatidylserine exposing erythrocytes were identified utilizing annexin-V-binding to phosphatidylserine, as determined by flow cytometry. Annexin-V-binding was analysed following an incubation of the erythrocytes for 48 hours in Ringer solution without or with bexarotene $(0.2-0.6 \mu \mathrm{g} /$ $\mathrm{ml}$ ). As illustrated in Fig. 1, a 48 hours treatment with bexarotene increased the percentage of phosphatidylserine exposing erythrocytes, an effect reaching statistical significance at $0.4 \mu \mathrm{gg} / \mathrm{ml}$ bexarotene.

A second hallmark of eryptosis is erythrocyte shrinkage. As a measure of erythrocyte volume forward scatter was determined utilizing flow cytometry. The measurements were performed after incubation for 48 hours in Ringer solution without or with bexarotene $(0.2-0.6 \mu \mathrm{g} / \mathrm{ml})$. As a result, the erythrocyte forward scatter was similar following exposure in the absence of bexarotene ( 496.5 \pm 8.8 a.u., $\mathrm{n}=14$ ) and in the presence of $0.2 \mu \mathrm{g} / \mathrm{ml}$ bexarotene $(482.5 \pm 7.6$ a.u., $\mathrm{n}=14), 0.4 \mu \mathrm{g} / \mathrm{ml}$ bexarotene (484.4 \pm 16.6 a.u., $\mathrm{n}=14$ ) and $0.6 \mu \mathrm{g} / \mathrm{ml}$ bexarotene (480.0 \pm 14.9 a.u., $n=14)$. Acordingly, bexarotene did not significantly modify erythrocyte forward scatter.

Eryptosis could be triggered by increase of cytosolic $\mathrm{Ca}^{2+}$ activity $\left(\left[\mathrm{Ca}^{2+}\right]_{\mathrm{i}}\right)$. Fluo3 fluorescence was employed in order to quantify $\left[\mathrm{Ca}^{2+}\right]_{\mathrm{i}}$. The erythrocytes were analyzed after a 48 hours incubation in Ringer solution without or with bexarotene $(0.2$ $-0.6 \mu \mathrm{g} / \mathrm{ml}$ ). As illustrated in

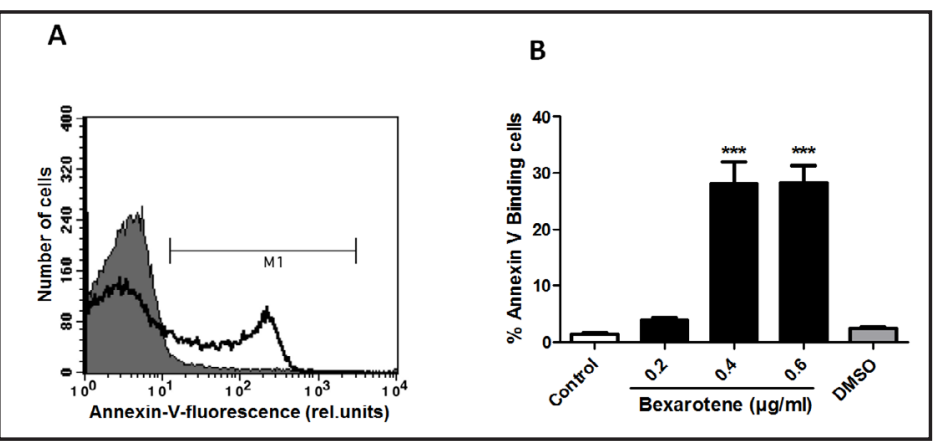

Fig. 1. Effect of bexarotene on phosphatidylserine exposure. A. Original histogram of annexin-V-binding of erythrocytes following exposure for 48 hours to Ringer solution without (grey area) and with (black line) presence of $0.6 \mu \mathrm{g} / \mathrm{ml}$ bexarotene. B. Arithmetic means \pm SEM $(\mathrm{n}=14)$ of erythrocyte annexin-V-binding following incubation for 48 hours to Ringer solution without (white bar) or with (black bars) bexarotene $(0.2-0.6 \mu \mathrm{g} / \mathrm{ml})$. For comparison, the effect of the solvent DMSO is shown (grey bar). ${ }^{* * *}(\mathrm{p}<0.001)$ indicates significant difference from the absence of bexarotene (ANOVA).

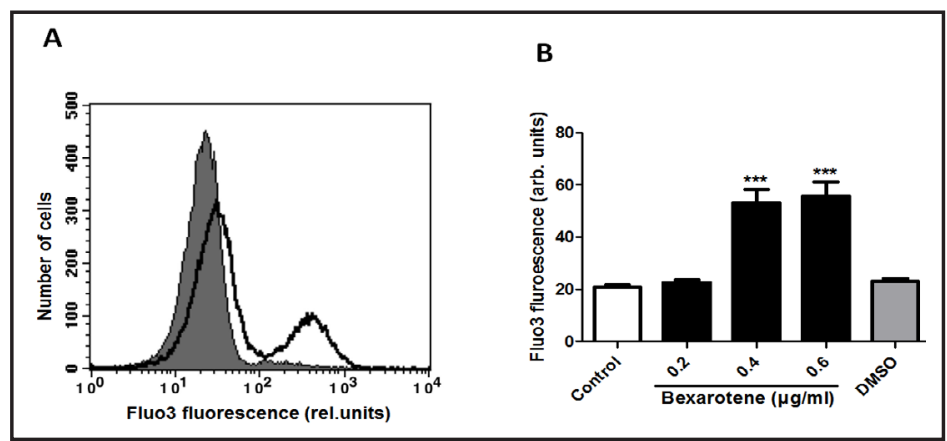

Fig. 2. Effect of bexarotene on cytosolic $\mathrm{Ca}^{2+}$ activity. A. Original histogram of Fluo3 fluorescence of erythrocytes following exposure for 48 hours to Ringer solution without (grey area) and with (black line) presence of $0.6 \mu \mathrm{g} / \mathrm{ml}$ bexarotene. B. Arithmetic means \pm SEM $(\mathrm{n}=14)$ of erythrocyte Fluo3 fluorescence following incubation for 48 hours to Ringer solution without (white bar) or with (black bars) bexarotene $(0.2-0.6 \mu \mathrm{g} / \mathrm{ml})$. For comparison, the effect of the solvent DMSO is shown (grey bar). ${ }^{* * *}(\mathrm{p}<0.001)$ indicates significant difference from the absence of bexarotene (ANOVA). 
Fig. 2, a 48 hours exposure to bexarotene increased the Fluo3 fluorescence, an effect reaching statistical significance at $0.4 \mu \mathrm{g} / \mathrm{ml}$ bexarotene.

In order to test wheth-
er bexarotene-induced translocation of phosphatidylserine to the outside required entry of extracellular $\mathrm{Ca}^{2+}$, erythrocytes were incubated for 48 hours in the absence or presence of $0.6 \mu \mathrm{g} / \mathrm{ml}$ bexarotene in the presence or nominal absence of extracellular $\mathrm{Ca}^{2+}$. As illustrated in Fig. 3, removal of extracellular $\mathrm{Ca}^{2+}$ significantly blunted the effect of bexarotene on annexin-V-binding. However, even in the absence of extracellular $\mathrm{Ca}^{2+}$, bexarotene significantly increased the percentage of annexin- $\mathrm{V}$ binding erythrocytes. Thus, the bexarotene-induced cell membrane scrambling was in part but not fully triggered by entry of extracellular $\mathrm{Ca}^{2+}$.

Eryptosis is further stimulated by oxidative stress. Reactive oxygen species (ROS) was thus quantified utilizing $2^{\prime}, 7^{\prime}$-dichlorodihydrofluorescein diacetate (DCFDA). As illustrated in Fig. 4, a 48 hours exposure to bexarotene $(0.6$ $\mu \mathrm{g} / \mathrm{ml}$ ) increased the DCFDA fluorescence of erythrocytes. The observations suggest that bexarotene did induce oxidative stress.

A further stimulator of eryptosis is ceramide. Ceramide abundance at the erythrocyte surface was quantified utilizing specific antibodies. As a result, the ceramide abundance tended to be higher following exposure to $0.6 \mu \mathrm{g} / \mathrm{ml}$ bexarotene $(22.0 \pm 1.7$ a.u., $\mathrm{n}=10)$ than following incubation in the absence of bexarotene (18.8 \pm 0.6 a.u., $n=10)$, a difference, however, not reaching statistical significance.

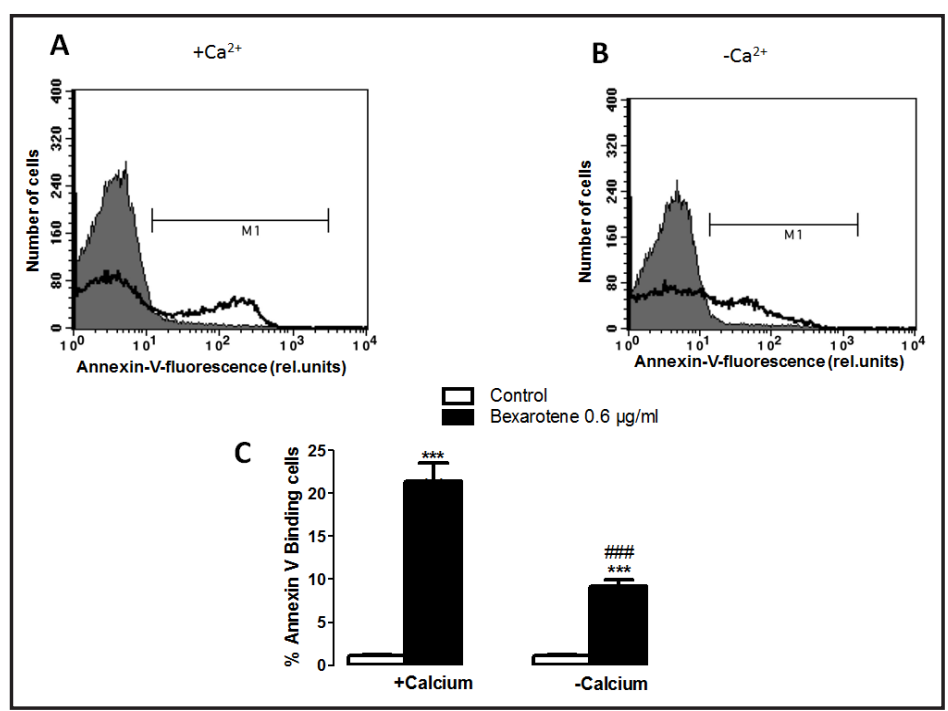

Fig. 3. $\mathrm{Ca}^{2+}$ sensitivity of bexarotene-induced phosphatidylserine exposure. A, B. Original histograms of annexin-V-binding of erythrocytes following exposure for 48 hours to Ringer solution without (grey areas) and with (black lines) bexarotene $(0.6 \mu \mathrm{g} / \mathrm{ml})$ in the presence (A) and absence $(\mathrm{B})$ of extracellular $\mathrm{Ca}^{2+}$. C. Arithmetic means \pm SEM ( $\mathrm{n}=$ 10) of annexin-V-binding of erythrocytes after a 48 hours treatment with Ringer solution without (white bars) or with (black bars) bexarotene $(0.6 \mu \mathrm{g} / \mathrm{ml})$ in the presence (left bars, $\left.+\mathrm{Ca}^{2+}\right)$ and absence (right bars, $\left.-\mathrm{Ca}^{2+}\right)$ of $\mathrm{Ca}^{2+} .{ }^{* * *}(\mathrm{p}<0.001)$ indicates significant difference from the absence of bexarotene, \#\#\#(p<0.001) indicates significant difference from the presence of $\mathrm{Ca}^{2+}$ (ANOVA).

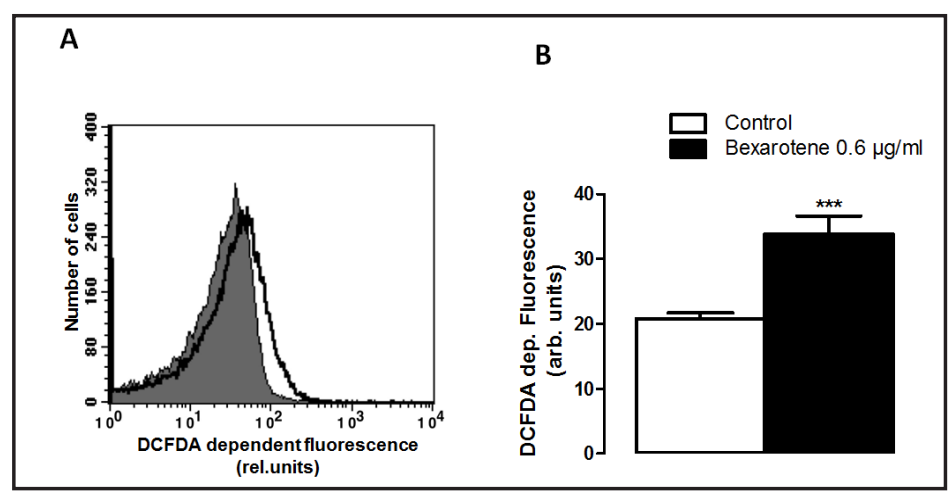

Fig. 4. Effect of bexarotene on reactive oxygen species. A. Original histogram of DCFDA fluorescence in erythrocytes following exposure for 48 hours to Ringer solution without (grey area) and with (black line) presence of $0.6 \mu \mathrm{g} / \mathrm{ml}$ bexarotene. B. Arithmetic means \pm SEM $(n=9)$ of DCFDA fluorescence in erythrocytes following incubation for 48 hours to Ringer solution without (white bar) or with (black bar) bexarotene $(0.6 \mu \mathrm{g} / \mathrm{ml}) .{ }^{* * *}(\mathrm{p}<0.01)$ indicates significant difference from the $\mathrm{ab}$ sence of bexarotene (unpaired $t$ test). 


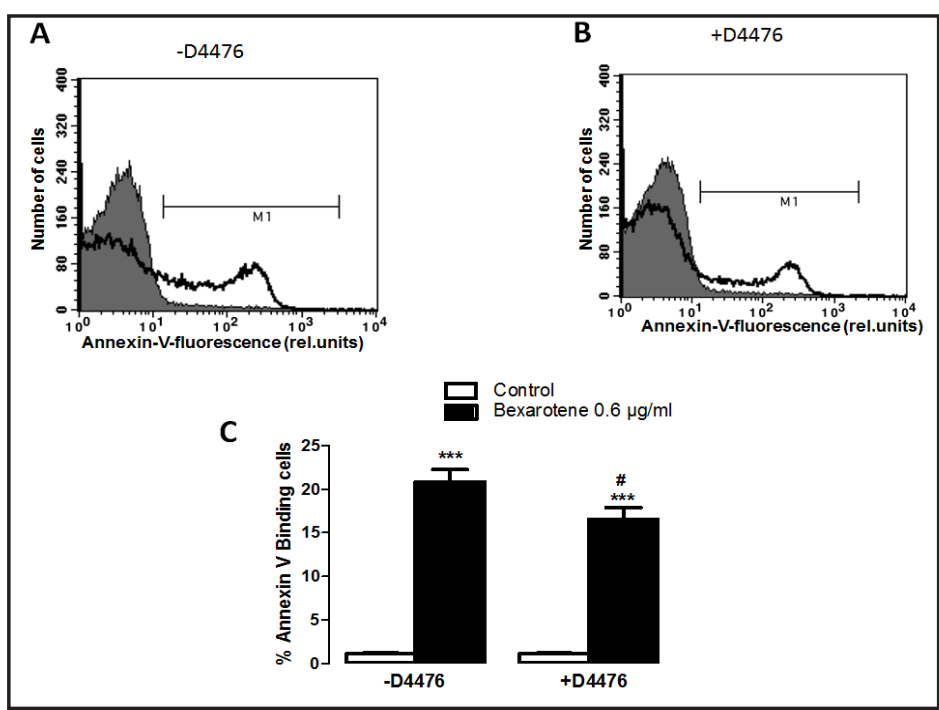

Fig. 5. D4476 sensitivity of bexarotene-induced phosphatidylserine exposure. A, B. Original histograms of annexin-V-binding of erythrocytes following exposure for 48 hours to Ringer solution without (grey areas) and with (black lines) bexarotene $(0.6 \mu \mathrm{g} / \mathrm{ml})$ in the absence (A) and presence (B) of casein kinase inhibitor D4476 $(10 \mu \mathrm{M})$. C. Arithmetic means \pm SEM $(n=9)$ of annexin-V-binding of erythrocytes after a 48 hours treatment with Ringer solution without (white bars) or with (black bars) bexarotene $(0.6 \mu \mathrm{g} / \mathrm{ml})$ in the absence (left bars, -D4476) and presence (right bars, +D4476) of casein kinase inhibitor $\mathrm{D} 4476(10 \mu \mathrm{M}) .{ }^{* * *}(\mathrm{p}<0.001)$ indicates significant difference from the absence of bexarotene, $\#(\mathrm{p}<0.05)$ indicates significant difference from the presence of D4476 (10 $\mu \mathrm{M})$ (ANOVA).

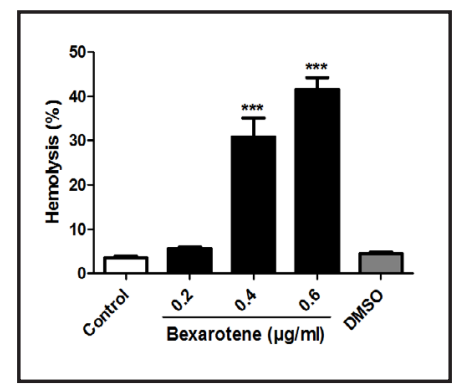

Fig. 6. Effect of bexarotene on hemolysis. Arithmetic means \pm SEM $(n=5)$ of the percentage of hemolyzed erythrocytes following incubation for 48 hours to Ringer solution without (white bar) or with (black bars) bexarotene $(0.2-0.6 \mu \mathrm{g} / \mathrm{ml})$. For comparison, the effect of the solvent DMSO is shown (grey bar). *** $(\mathrm{p}<0.001)$ indicates significant difference from the absence of bexarotene (ANOVA).

To explore, whether the effects of bexarotene involved kinase activity, the influence of bexarotene on annexin-V-binding was tested in the presence of p38 kinase inhibitor SB203580, of protein kinase C inhibitor staurosporine, or of casein kinase 1 inhibitor D4476. As a result, bexarotene $(0.6 \mu \mathrm{g} / \mathrm{ml})$ increased the percentage of phosphatidylserine exposing erythrocytes to similar values following incubation in the absence (from $1.2 \pm 0.1 \%$ to 23.1 $\pm 1.6 \%, \mathrm{n}=10$ ) and in the presence (from $1.3 \pm 0.1 \%$ to $24.5 \pm 4.0 \%, \mathrm{n}=10$ ) of SB203580 $(2 \mu \mathrm{M})$. Bexarotene $(0.6 \mu \mathrm{g} / \mathrm{ml})$ further increased the percentage of phosphatidylserine exposing erythrocytes to similar values following incubation in the absence (from $1.4 \pm 0.3$ $\%$ to $28.4 \pm 2.0 \%, \mathrm{n}=15$ ) and in the presence (from $2.9 \pm 0.3 \%$ to $31.8 \pm 2.6 \%, \mathrm{n}=15$ ) of staurosporine $(1 \mu \mathrm{M})$. As illustrated in Fig. 5, D4476 $(10 \mu \mathrm{M})$ significantly blunted the effect of bexarotene on annexin-V-binding. However, even in the presence of D4476, bexarotene significantly increased the percentage of annexin-V-binding erythrocytes. Accordingly, bexarotene-induced cell membrane scrambling was in part but not fully dependent on D4476 sensitive casein kinase 1.

To test whether the effects of bexarotene involved caspases, the influence of bexarotene on annexin-V-binding was tested in the presence of pancaspase inhibitor zVAD. As a result, bexarotene $(0.6 \mu \mathrm{g} / \mathrm{ml})$ increased the percentage of phosphatidylserine exposing erythrocytes to similar values following incubation in the absence (from $1.3 \pm 0.1 \%$ to 18.7 $\pm 1.1 \%, \mathrm{n}=5$ ) and in the presence (from $2.2 \pm 0.5 \%$ to $20.6 \pm 2.4 \%, \mathrm{n}=5)$ of $\mathrm{zVAD}(10 \mu \mathrm{M})$.

A final series of experiments addressed the influence of bexarotene on hemolysis. The percentage of hemolytic cells was quantified from the hemoglobin concentration in the supernatant. As illustrated in Fig. 6, a 48 hours exposure to bexarotene increased the percentage of hemolytic erythrocytes, an effect reaching statistical significance at $0.4 \mu \mathrm{g} / \mathrm{ml}$ bexarotene. 


\section{Discussion}

The present observations reveal that bexarotene stimulates cell membrane scrambling with phosphatidylserine translocation to the erythrocyte surface, a hallmark of eryptosis, i.e. of suicidal erythrocyte death. The bexarotene concentrations required for the stimulation of eryptosis are well in the range of concentrations $(0.2-6 \mu \mathrm{g} / \mathrm{ml})$ encountered in the plasma of patients $[110,111]$. The stimulation of eryptosis may thus well explain the anemia following bexarotene treatment [49].

The effect of bexarotene on cell membrane scrambling was paralleled by an increase of cytosolic $\mathrm{Ca}^{2+}$ activity $\left(\left[\mathrm{Ca}^{2+}\right]_{\mathrm{i}}\right)$ and was in large part dependent on $\mathrm{Ca}^{2+}$ entry from the extracellular space. Removal of extracellular $\mathrm{Ca}^{2+}$ significantly blunted the bexarotene induced eryptosis. However, bexarotene triggered cell membrane scrambling even in the nominal absence of extracellular $\mathrm{Ca}^{2+}$, an observation pointing to the involvement of additional mechanisms contributing to bexarotene induced cell membrane scrambling. Cells could be sensitized for the scrambling effect of $\mathrm{Ca}^{2+}$ by ceramide [50]. Bexarotene treatment tended to increase the ceramide abundance, an effect not reaching statistical significance. Bexarotene significantly enhanced the abundance of reactive oxygen species, a well known trigger of eryptosis [50]. Bexarotene is therefore partially effective by inducing oxidative stress. The effect of bexarotene did not require the activity of SB203580 sensitive p38 kinase or of staurosporine sensitive kinases such as protein kinase C. Both kinases participate in the orchestration of eryptosis by other stimuli [50]. The bexarotene induced cell membrane scrambling was slightly, but sigificantly blunted by casein kinase 1 inhibitor D4476 and may involve the casein kinase 1, a known stimulator of eryptosis [50].

The effect of bexarotene on cell membrane scrambling was not paralleled by appreciable erythrocyte shrinkage. This observation is surprising in view of the marked increase of $\left[\mathrm{Ca}^{2+}\right]_{\mathrm{i}}$ which were expected to activate $\mathrm{Ca}^{2+}$ sensitive $\mathrm{K}^{+}$channels leading to $\mathrm{K}^{+}$exit, cell membrane hyperpolarization, $\mathrm{Cl}^{-}$exit and thus cellular loss of $\mathrm{KCl}$ with water. The underlying mechanism accounting for the failure of bexarotene treated erythrocytes to shrink remained elusive. Potential mechanisms include an inhibitory effect on the $\mathrm{Na}^{+} / \mathrm{K}^{+}$ATPase with decrease of cellular $\mathrm{K}^{+}$concentration and thus failure to hyperpolarize following activation of $\mathrm{K}^{+}$channels. Alternatively erythrocyte shrinkage could be prevented by inhibition of $\mathrm{K}^{+}$or $\mathrm{Cl}^{-}$channels.

Inability to release $\mathrm{K}^{+}$and $\mathrm{Cl}^{-}$through the respective ion channels would not only be expected to disrupt cell shrinkage but may actually lead to cell swelling. Excessive cell swelling may be followed by disruption of the cell membrane, a key event of hemolysis. In vivo eryptosis aims to accomplish clearance of defective erythrocytes from circulating blood prior to hemolysis [50]. The hemoglobin released following hemolysis may otherwise pass the renal glomerular filter, precipitate in the acidic lumen of renal tubules, occlude nephrons and may thus lead to renal failure [112].

The clearance of phosphatidylserine exposing erythrocytes may lead to anemia as soon as the loss of erythrocytes surpasses the formation of new erythrocytes by erythropoiesis [50]. Phosphatidylserine exposing erythrocytes further adhere to the vascular wall [113], stimulate blood clotting and trigger thrombosis [114-116], and may thus interfere with microcirculation [52,114, 117-120].

In conclusion, bexarotene triggers erythrocyte cell membrane scrambling, an effect in part due to $\mathrm{Ca}^{2+}$ entry, oxidative stress and activation of D4476 sensitive casein kinase 1 .

\section{Acknowledgements}

The authors acknowledge the meticulous preparation of the manuscript by Tanja Loch. The study was supported by the Deutsche Forschungsgemeinschaft and Open Access Publishing Fund of Tuebingen University. 


\section{Cellular Physiology Cell Physiol Biochem 2016;40:1239-1251

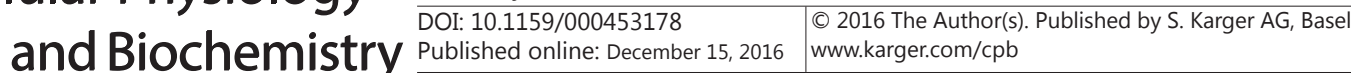 \\ Bhuyan et al.: Bexarotene-Induced Eryptosis}

\section{Disclosure Statement}

All authors declare that there are no conflicts of interest.

\section{References}

1 Qi L, Guo Y, Zhang P, Cao X, Luan Y: Preventive and Therapeutic Effects of the Retinoid X Receptor Agonist Bexarotene on Tumors. Curr Drug Metab 2016;17:118-128.

2 Furmick JK, Kaneko I, Walsh AN, Yang J, Bhogal JS, Gray GM, Baso JC, Browder DO, Prentice JL, Montano LA, Huynh CC, Marcus LM, Tsosie DG, Kwon JS, Quezada A, Reyes NM, Lemming B, Saini P, van der Vaart A, Groy TL, Marshall PA, Jurutka PW, Wagner CE: Modeling, synthesis and biological evaluation of potential retinoid X receptor-selective agonists: novel halogenated analogues of 4-[1-(3,5,5,8,8-pentamethyl-5,6,7,8tetrahydro-2-naphthyl)ethynyl]benzoic acid (bexarotene). ChemMedChem 2012;7:1551-1566.

3 Scarisbrick JJ, Morris S, Azurdia R, Illidge T, Parry E, Graham-Brown R, Cowan R, Gallop-Evans E, Wachsmuth R, Eagle M, Wierzbicki AS, Soran H, Whittaker S, Wain EM: U.K. consensus statement on safe clinical prescribing of bexarotene for patients with cutaneous T-cell lymphoma. Br J Dermatol 2013;168:192-200.

$4 \quad$ Qu L, Tang X: Bexarotene: a promising anticancer agent. Cancer Chemother Pharmacol 2010;65:201-205.

5 Querfeld C, Nagelli LV, Rosen ST, Kuzel TM, Guitart J: Bexarotene in the treatment of cutaneous T-cell lymphoma. Expert Opin Pharmacother 2006;7:907-915.

6 Lowe MN, Plosker GL: Bexarotene. Am J Clin Dermatol 2000;1:245-250; discussion 251-242.

7 Asteria C: Treatment with retinoid X receptorgamma-selective ligand (bexarotene) may cause iatrogenic central hypothyroidism. Eur J Endocrinol 2000;142:324-325.

8 Lin JH, Kim EJ, Bansal A, Seykora J, Richardson SK, Cha XY, Zafar S, Nasta S, Wysocka M, Benoit B, Rook AH, Fakharzadeh SS: Clinical and in vitro resistance to bexarotene in adult T-cell leukemia: loss of RXR-alpha receptor. Blood 2008;112:2484-2488.

9 Panchal MR, Scarisbrick JJ: The utility of bexarotene in mycosis fungoides and Sezary syndrome. Onco Targets Ther 2015;8:367-373.

10 Quereux G, Saint-Jean M, Peuvrel L, Brocard A, Knol AC, Dreno B: Bexarotene in cutaneous T-cell lymphoma: third retrospective study of long-term cohort and review of the literature. Expert Opin Pharmacother 2013;14:1711-1721.

11 Pileri A, Delfino C, Grandi V, Pimpinelli N: Role of bexarotene in the treatment of cutaneous T-cell lymphoma: the clinical and immunological sides. Immunotherapy 2013;5:427-433.

12 Gopaluni S, Perzova R, Abbott L, Farah R, Shrimpton A, Hutchison R, Poiesz BJ: CD8+ cutaneous T-cell lymphoma successfully treated with bexarotene: a case report and review of the literature. Am J Hematol 2008;83:744-746.

13 Gniadecki R, Assaf C, Bagot M, Dummer R, Duvic M, Knobler R, Ranki A, Schwandt P, Whittaker S: The optimal use of bexarotene in cutaneous T-cell lymphoma. Br J Dermatol 2007;157:433-440.

14 Assaf C, Bagot M, Dummer R, Duvic M, Gniadecki R, Knobler R, Ranki A, Schwandt P, Whittaker S: Minimizing adverse side-effects of oral bexarotene in cutaneous T-cell lymphoma: an expert opinion. Br J Dermatol 2006;155:261-266.

15 Singh F, Lebwohl MG: Cutaneous T-cell lymphoma treatment using bexarotene and PUVA: a case series. J Am Acad Dermatol 2004;51:570-573.

16 Farol LT, Hymes KB: Bexarotene: a clinical review. Expert Rev Anticancer Ther 2004;4:180-188.

17 McGinnis KS, Junkins-Hopkins JM, Crawford G, Shapiro M, Rook AH, Vittorio CC: Low-dose oral bexarotene in combination with low-dose interferon alfa in the treatment of cutaneous T-cell lymphoma: clinical synergism and possible immunologic mechanisms. J Am Acad Dermatol 2004;50:375-379.

18 Martin AG: Bexarotene gel: a new skin-directed treatment option for cutaneous T-cell lymphomas. J Drugs Dermatol 2003;2:155-167.

19 McGinnis KS, Shapiro M, Vittorio CC, Rook AH, Junkins-Hopkins JM: Psoralen plus long-wave UV-A (PUVA) and bexarotene therapy: An effective and synergistic combined adjunct to therapy for patients with advanced cutaneous T-cell lymphoma. Arch Dermatol 2003;139:771-775.

20 Sherman SI: Etiology, diagnosis, and treatment recommendations for central hypothyroidism associated with bexarotene therapy for cutaneous T-cell lymphoma. Clin Lymphoma 2003;3:249-252. 


\section{Cellular Physiology Cell Physiol Biochem 2016;40:1239-1251

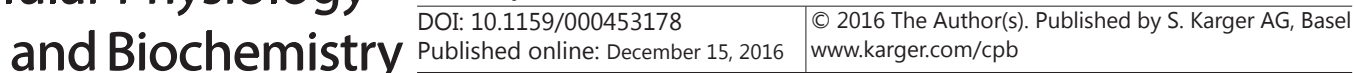 \\ Bhuyan et al.: Bexarotene-Induced Eryptosis}

21 Duvic M: Bexarotene and DAB(389)IL-2 (denileukin diftitox, ONTAK) in treatment of cutaneous T-cell lymphomas: algorithms. Clin Lymphoma 2000;1 Suppl 1:S51-55.

22 Hurst RE: Bexarotene ligand pharmaceuticals. Curr Opin Investig Drugs 2000;1:514-523.

23 Wong SF: Oral bexarotene in the treatment of cutaneous T-cell lymphoma. Ann Pharmacother 2001;35:1056-1065.

24 Knol AC, Quereux G, Brocard A, Ballanger F, Khammari A, Nguyen JM, Dreno B: About the cutaneous targets of bexarotene in CTCL patients. Exp Dermatol 2010;19:e299-301.

25 Steinhoff M, Beyer M, Roewert-Huber J, Lukowsky A, Assaf C, Sterry W: Complete clinical remission of tumor-stage mycosis fungoides after acute extensive skin necroses, granulomatous reaction, and fever under treatment with bexarotene, vorinostat, and high-dose fenofibrate. J Am Acad Dermatol 2008;58:S8891.

26 Brennand S, Sutton VR, Biagi J, Trapani JA, Westerman D, McCormack CJ, Seymour JF, Kennedy G, Prince HM: Lack of apoptosis of Sezary cells in the circulation following oral bexarotene therapy. Br J Dermatol 2005;152:1199-1205.

27 Budgin JB, Richardson SK, Newton SB, Wysocka M, Zaki MH, Benoit B, Rook AH: Biological effects of bexarotene in cutaneous T-cell lymphoma. Arch Dermatol 2005;141:315-321.

28 Zhang C, Hazarika P, Ni X, Weidner DA, Duvic M: Induction of apoptosis by bexarotene in cutaneous T-cell lymphoma cells: relevance to mechanism of therapeutic action. Clin Cancer Res 2002;8:1234-1240.

29 Rigas JR, Dragnev KH: Emerging role of rexinoids in non-small cell lung cancer: focus on bexarotene. Oncologist 2005;10:22-33.

30 Dragnev KH, Petty WJ, Shah SJ, Lewis LD, Black CC, Memoli V, Nugent WC, Hermann T, Negro-Vilar A, Rigas JR, Dmitrovsky E: A proof-of-principle clinical trial of bexarotene in patients with non-small cell lung cancer. Clin Cancer Res 2007;13:1794-1800.

31 Kong JN, He Q, Wang G, Dasgupta S, Dinkins MB, Zhu G, Kim A, Spassieva S, Bieberich E: Guggulsterone and bexarotene induce secretion of exosome-associated breast cancer resistance protein and reduce doxorubicin resistance in MDA-MB-231 cells. Int J Cancer 2015;137:1610-1620.

32 Kim HT, Kong G, Denardo D, Li Y, Uray I, Pal S, Mohsin S, Hilsenbeck SG, Bissonnette R, Lamph WW, Johnson K, Brown PH: Identification of biomarkers modulated by the rexinoid LGD1069 (bexarotene) in human breast cells using oligonucleotide arrays. Cancer Res 2006;66:12009-12018.

33 Yen WC, Lamph WW: The selective retinoid X receptor agonist bexarotene (LGD1069, Targretin) prevents and overcomes multidrug resistance in advanced breast carcinoma. Mol Cancer Ther 2005;4:824-834.

34 Janakiram NB, Mohammed A, Zhang Y, Brewer M, Bryant T, Lightfoot S, Steele VE, Rao CV: Chemopreventive efficacy of raloxifene, bexarotene, and their combination on the progression of chemically induced colon adenomas to adenocarcinomas in rats. Cancer Prev Res (Phila) 2013;6:1251-1261.

35 Abba MC, Hu Y, Levy CC, Gaddis S, Kittrell FS, Zhang Y, Hill J, Bissonnette RP, Medina D, Brown PH, Aldaz CM: Transcriptomic signature of bexarotene (rexinoid LGD1069) on mammary gland from three transgenic mouse mammary cancer models. BMC Med Genomics 2008;1:40.

36 Li Y, Zhang Y, Hill J, Kim HT, Shen Q, Bissonnette RP, Lamph WW, Brown PH: The rexinoid, bexarotene, prevents the development of premalignant lesions in MMTV-erbB2 mice. Br J Cancer 2008;98:1380-1388.

37 Wang Y, Wen W, Yi Y, Zhang Z, Lubet RA, You M: Preventive effects of bexarotene and budesonide in a genetically engineered mouse model of small cell lung cancer. Cancer Prev Res (Phila) 2009;2:1059-1064.

38 Sanli H, Akay BN, Ozcan M: Development of Hodgkin's lymphoma under bexarotene treatment for Sezary syndrome and review of the literature. J Drugs Dermatol 2010;9:1014-1016.

39 Smit JV, de Jong EM, van Hooijdonk CA, Otero ME, Boezeman JB, van de Kerkhof PC: Systemic treatment of psoriatic patients with bexarotene decreases epidermal proliferation and parameters for inflammation, and improves differentiation in lesional skin. J Am Acad Dermatol 2004;51:257-264.

40 Zhong J, Cheng C, Liu H, Huang Z, Wu Y, Teng Z, He J, Zhang H, Wu J, Cao F, Jiang L, Sun X: Bexarotene protects against traumatic brain injury in mice partially through apolipoprotein E. Neuroscience 2016;10.1016/j.neuroscience.2016.05.033

41 Tousi B: The emerging role of bexarotene in the treatment of Alzheimer's disease: current evidence. Neuropsychiatr Dis Treat 2015;11:311-315.

42 Nieto-Rementeria N, Perez-Yarza G, Boyano MD, Apraiz A, Izu R, Diaz-Perez JL, Asumendi A: Bexarotene activates the p53/p73 pathway in human cutaneous T-cell lymphoma. Br J Dermatol 2009;160:519-526. 


\section{Cellular Physiology Cell Physiol Biochem 2016;40:1239-1251 \begin{tabular}{l|l|l|} 
and BOI: 10.1159/000453178 & $\begin{array}{l}\text { C) 2016 The Author(s). Published by S. Karger AG, Basel } \\
\text { www.karger.com/cpb }\end{array}$
\end{tabular} \\ Bhuyan et al.: Bexarotene-Induced Eryptosis}

43 Shilkaitis A, Bratescu L, Green A, Yamada T, Christov K: Bexarotene induces cellular senescence in MMTVNeu mouse model of mammary carcinogenesis. Cancer Prev Res (Phila) 2013;6:299-308.

44 Wang Y, Rong J, Zhang J, Liu Y, Meng X, Guo H, Liu H, Chen L: Morphology, in vivo distribution and antitumor activity of bexarotene nanocrystals in lung cancer. Drug Dev Ind Pharm 2016;10.1080/03639045.2016.12257521-10.

45 Zhang Q, Pan J, Zhang J, Liu P, Chen R, Chen DR, Lubet R, Wang Y, You M: Aerosolized bexarotene inhibits lung tumorigenesis without increasing plasma triglyceride and cholesterol levels in mice. Cancer Prev Res (Phila) 2011;4:270-276.

46 Wagner CE, Jurutka PW, Marshall PA, Groy TL, van der Vaart A, Ziller JW, Furmick JK, Graeber ME, Matro E, Miguel BV, Tran IT, Kwon J, Tedeschi JN, Moosavi S, Danishyar A, Philp JS, Khamees RO, Jackson JN, Grupe DK, Badshah SL, Hart JW: Modeling, synthesis and biological evaluation of potential retinoid X receptor (RXR) selective agonists: novel analogues of 4-[1-(3,5,5,8,8-pentamethyl-5,6,7,8-tetrahydro-2-naphthyl) ethynyl]benzoic acid (bexarotene). J Med Chem 2009;52:5950-5966.

47 Talpur R, Vu J, Bassett R, Stevens V, Duvic M: Phase I/II randomized bilateral half-head comparison of topical bexarotene 1\% gel for alopecia areata. J Am Acad Dermatol 2009;61:592 e591-599.

48 Ying SX, Seal S, Abbassi N, Hockenbery DM, Kiem HP, Li X, Pagel JM, Gopal AK, Deeg HJ: Differential effects of bexarotene on intrinsic and extrinsic pathways in TRAIL-induced apoptosis in two myeloid leukemia cell lines. Leuk Lymphoma 2007;48:1003-1014.

49 Hamada T, Sugaya M, Tokura Y, Ohtsuka M, Tsuboi R, Nagatani T, Tani M, Setoyama M, Matsushita S, Kawai K, Yonekura K, Yoshida T, Saida T, Iwatsuki K: Phase I/II study of the oral retinoid X receptor agonist bexarotene in Japanese patients with cutaneous T-cell lymphomas. J Dermatol 2016;10.1111/13468138.13542

50 Lang E, Lang F: Mechanisms and pathophysiological significance of eryptosis, the suicidal erythrocyte death. Semin Cell Dev Biol 2015;39:35-42.

51 Lang PA, Kaiser S, Myssina S, Wieder T, Lang F, Huber SM: Role of Ca2+-activated K+ channels in human erythrocyte apoptosis. Am J Physiol Cell Physiol 2003;285:C1553-C1560.

52 Abed M, Towhid ST, Mia S, Pakladok T, Alesutan I, Borst O, Gawaz M, Gulbins E, Lang F: Sphingomyelinaseinduced adhesion of eryptotic erythrocytes to endothelial cells. Am J Physiol Cell Physiol 2012;303:C991999.

53 Lau IP, Chen H, Wang J, Ong HC, Leung KC, Ho HP, Kong SK: In vitro effect of CTAB- and PEG-coated gold nanorods on the induction of eryptosis/erythroptosis in human erythrocytes. Nanotoxicology 2012;6:847856.

54 Maellaro E, Leoncini S, Moretti D, Del Bello B, Tanganelli I, De Felice C, Ciccoli L: Erythrocyte caspase-3 activation and oxidative imbalance in erythrocytes and in plasma of type 2 diabetic patients. Acta Diabetol 2013;50:489-495.

55 Alzoubi K, Calabrò S, Bissinger R, Abed M, Faggio C, Lang F: Stimulation of Suicidal Erythrocyte Death by Artesunate. Cell Physiol Biochem 2014;34:2232-2244.

56 Alzoubi K, Egler J, Abed M, Lang F: Enhanced Eryptosis Following Auranofin Exposure. Cell Physiol Biochem 2015;37:1018-1028.

57 Arnold M, Bissinger R, Lang F: Mitoxantrone-induced suicidal erythrocyte death. Cell Physiol Biochem 2014;34:1756-1767.

58 Arnold M, Lang E, Modicano P, Bissinger R, Faggio C, Abed M, Lang F: Effect of nitazoxanide on erythrocytes. Basic Clin Pharmacol Toxicol 2014;114:421-426.

59 Bissinger R, Barking S, Alzoubi K, Liu G, Liu G, Lang F: Stimulation of Suicidal Erythrocyte Death by the Antimalarial Drug Mefloquine. Cell Physiol Biochem 2015;36:1395-1405.

60 Bissinger R, Bouguerra G, Stockinger K, Abbes S, Lang F: Triggering of Suicidal Erythrocyte Death by Topotecan. Cell Physiol Biochem 2015;37:1607-1618.

61 Bissinger R, Fischer S, Jilani K, Lang F: Stimulation of Erythrocyte Death by Phloretin. Cell Physiol Biochem 2014;34:2256-2265.

62 Bissinger R, Lupescu A, Zelenak C, Jilani K, Lang F: Stimulation of eryptosis by cryptotanshinone. Cell Physiol Biochem 2014;34:432-442.

63 Bouguerra G, Aljanadi O, Bissinger R, Abbes S, Lang F: Embelin-Induced Phosphatidylserine Translocation in the Erythrocyte Cell Membrane. Cell Physiol Biochem 2015;37:1629-1640. 


\section{Cellular Physiology Cell Physiol Biochem 2016;40:1239-1251 \begin{tabular}{l|l|l} 
and Biochemistry & Dublished online: December 15, 2016 & $\begin{array}{l}\text { (c) } 2016 \text { The Author(s). Published by S. Karger AG, Basel } \\
\text { www.karger.com/cpb }\end{array}$
\end{tabular} \\ Bhuyan et al.: Bexarotene-Induced Eryptosis}

64 Bouguerra G, Bissinger R, Abbes S, Lang F: Stimulation of Eryptosis by Narasin. Cell Physiol Biochem 2015;37:1807-1816.

65 Bouguerra G, Bissinger R, Abbes S, Lang F: Zopolrestat Induced Suicidal Death of Human Erythrocytes. Cell Physiol Biochem 2015;37:1537-1546.

66 Briglia M, Fazio A, Faggio C, Laufer S, Alzoubi K, Lang F: Triggering of Suicidal Erythrocyte Death by Ruxolitinib. Cell Physiol Biochem 2015;37:768-778.

67 Briglia M, Fazio A, Signoretto E, Faggio C, Lang F: Edelfosine Induced Suicidal Death of Human Erythrocytes. Cell Physiol Biochem 2015;37:2221-2230.

68 Calabro S, Alzoubi K, Faggio C, Laufer S, Lang F: Triggering of Suicidal Erythrocyte Death Following Boswellic Acid Exposure. Cell Physiol Biochem 2015;37:131-142.

69 Egler J, Lang F: Licochalcone A Induced Suicidal Death of Human Erythrocytes. Cell Physiol Biochem 2015;37:2060-2070.

70 Faggio C, Alzoubi K, Calabro S, Lang F: Stimulation of suicidal erythrocyte death by PRIMA-1. Cell Physiol Biochem 2015;35:529-540.

71 Fazio A, Briglia M, Faggio C, Alzoubi K, Lang F: Stimulation of Suicidal Erythrocyte Death by Garcinol. Cell Physiol Biochem 2015;37:805-815.

72 Jacobi J, Lang E, Bissinger R, Frauenfeld L, Modicano P, Faggio C, Abed M, Lang F: Stimulation of erythrocyte cell membrane scrambling by mitotane. Cell Physiol Biochem 2014;33:1516-1526.

73 Lang E, Jilani K, Bissinger R, Rexhepaj R, Zelenak C, Lupescu A, Lang F, Qadri SM: Vitamin D-Rich Diet in Mice Modulates Erythrocyte Survival. Kidney Blood Press Res 2015;40:403-412.

74 Lang E, Zelenak C, Eberhard M, Bissinger R, Rotte A, Ghashghaeinia M, Lupescu A, Lang F, Qadri SM: Impact of Cyclin-Dependent Kinase CDK4 Inhibition on Eryptosis. Cell Physiol Biochem 2015;37:1178-1186.

75 Lupescu A, Bissinger R, Goebel T, Salker MS, Alzoubi K, Liu G, Chirigiu L, Mack AF, Qadri SM, Lang F: Enhanced suicidal erythrocyte death contributing to anemia in the elderly. Cell Physiol Biochem 2015;36:773-783.

76 Lupescu A, Bissinger R, Herrmann T, Oswald G, Jilani K, Lang F: Induction of suicidal erythrocyte death by novobiocin. Cell Physiol Biochem 2014;33:670-680.

77 Lupescu A, Bissinger R, Warsi J, Jilani K, Lang F: Stimulation of erythrocyte cell membrane scrambling by gedunin. Cell Physiol Biochem 2014;33:1838-1848.

78 Malik A, Bissinger R, Calabro S, Faggio C, Jilani K, Lang F: Aristolochic Acid Induced Suicidal Erythrocyte Death. Kidney Blood Press Res 2014;39:408-419.

79 Officioso A, Alzoubi K, Manna C, Lang F: Clofazimine Induced Suicidal Death of Human Erythrocytes. Cell Physiol Biochem 2015;37:331-341.

80 Oswald G, Alzoubi K, Abed M, Lang F: Stimulation of suicidal erythrocyte death by ribavirin. Basic Clin Pharmacol Toxicol 2014;114:311-317.

81 Peter T, Bissinger R, Enkel S, Alzoubi K, Oswald G, Lang F: Programmed erythrocyte death following in vitro Treosulfan treatment. Cell Physiol Biochem 2015;35:1372-1380.

82 Stockinger K, Bissinger R, Bouguerra G, Abbes S, Lang F: Enhanced Eryptosis Following Exposure to Carnosic Acid. Cell Physiol Biochem 2015;37:1779-1791.

83 Tesoriere L, Attanzio A, Allegra M, Cilla A, Gentile C, Livrea MA: Oxysterol mixture in hypercholesterolemiarelevant proportion causes oxidative stress-dependent eryptosis. Cell Physiol Biochem 2014;34:10751089.

84 Waibel S, Bissinger R, Bouguerra G, Abbes S, Lang F: Saquinavir Induced Suicidal Death of Human Erythrocytes. Cell Physiol Biochem 2015;37:1973-1982.

85 Zierle J, Bissinger R, Egler J, Lang F: Lapatinib Induced Suicidal Death of Human Erythrocytes. Cell Physiol Biochem 2015;37:2275-2287.

86 Bissinger R, Bouguerra G, Al Mamun Bhuyan A, Waibel S, Abbes S, Lang F: Efavirenz Induced Suicidal Death of Human Erythrocytes. Cell Physiol Biochem 2015;37:2496-2507.

87 Bissinger R, Waibel S, Bouguerra G, Al Mamun Bhuyan A, Abbes S, Lang F: Enhanced Eryptosis Following Exposure to Lopinavir. Cell Physiol Biochem 2015;37:2486-2495.

88 Briglia M, Calabro S, Signoretto E, Alzoubi K, Laufer S, Faggio C, Lang F: Fucoxanthin Induced Suicidal Death of Human Erythrocytes. Cell Physiol Biochem 2015;37:2464-2475.

89 Briglia M, Fazio A, Faggio C, Lang F: Triggering of Suicidal Erythrocyte Death by Zosuquidar. Cell Physiol Biochem 2015;37:2355-2365. 


\section{Cellular Physiology Cell Physiol Biochem 2016;40:1239-1251 \begin{tabular}{l|l|l|}
\hline DOI: 10.1159/000453178 & $\begin{array}{l}\text { C } 2016 \text { The Author(s). Published by S. Karger AG, Basel } \\
\text { www.karger.com/cpb }\end{array}$ \\
\hline
\end{tabular} \\ Bhuyan et al.: Bexarotene-Induced Eryptosis}

90 Fazio A, Briglia M, Faggio C, Alzoubi K, Lang F: Oxaliplatin Induced Suicidal Death of Human Erythrocytes. Cell Physiol Biochem 2015;37:2393-2404.

91 Macczak A, Cyrkler M, Bukowska B, Michalowicz J: Eryptosis-inducing activity of bisphenol A and its analogs in human red blood cells (in vitro study). J Hazard Mater 2016;307:328-335.

92 Officioso A, Alzoubi K, Lang F, Manna C: Hydroxytyrosol inhibits phosphatidylserine exposure and suicidal death induced by mercury in human erythrocytes: Possible involvement of the glutathione pathway. Food Chem Toxicol 2016;89:47-53.

93 Officioso A, Manna C, Alzoubi K, Lang F: Bromfenvinphos induced suicidal death of human erythrocytes. Pestic Biochem Physiol 2016;126:58-63.

94 Qadri SM, Donkor DA, Bhakta V, Eltringham-Smith LJ, Dwivedi DJ, Moore JC, Pepler L, Ivetic N, Nazi I, Fox-Robichaud AE, Liaw PC, Sheffield WP: Phosphatidylserine externalization and procoagulant activation of erythrocytes induced by Pseudomonas aeruginosa virulence factor pyocyanin. J Cell Mol Med 2016;10.1111/jcmm.12778

95 Zierle J, Bissinger R, Bouguerra G, Abbes S, Lang F: Triggering of Suicidal Erythrocyte Death by Regorafenib. Cell Physiol Biochem 2016;38:160-172.

96 Pagano M, Faggio C: The use of erythrocyte fragility to assess xenobiotic cytotoxicity. Cell Biochem Funct 2015;33:351-355.

97 Bissinger R, Modicano P, Alzoubi K, Honisch S, Faggio C, Abed M, Lang F: Effect of saponin on erythrocytes. Int J Hematol 2014;100:51-59.

98 Bissinger R, Modicano P, Frauenfeld L, Lang E, Jacobi J, Faggio C, Lang F: Estramustine-induced suicidal erythrocyte death. Cell Physiol Biochem 2013;32:1426-1436.

99 Lang E, Modicano P, Arnold M, Bissinger R, Faggio C, Abed M, Lang F: Effect of thioridazine on erythrocytes. Toxins (Basel) 2013;5:1918-1931.

100 Abed M, Feger M, Alzoubi K, Pakladok T, Frauenfeld L, Geiger C, Towhid ST, Lang F: Sensitization of erythrocytes to suicidal erythrocyte death following water deprivation. Kidney Blood Press Res 2013;37:567-578.

101 Voelkl J, Alzoubi K, Mamar AK, Ahmed MS, Abed M, Lang F: Stimulation of suicidal erythrocyte death by increased extracellular phosphate concentrations. Kidney Blood Press Res 2013;38:42-51.

102 Abed M, Artunc F, Alzoubi K, Honisch S, Baumann D, Foller M, Lang F: Suicidal erythrocyte death in endstage renal disease. J Mol Med (Berl) 2014;92:871-879.

103 Ahmed MS, Langer H, Abed M, Voelkl J, Lang F: The uremic toxin acrolein promotes suicidal erythrocyte death. Kidney Blood Press Res 2013;37:158-167.

104 Polak-Jonkisz D, Purzyc L: Ca(2+) influx versus efflux during eryptosis in uremic erythrocytes. Blood Purif 2012;34:209-210; author reply 210.

105 Calderon-Salinas JV, Munoz-Reyes EG, Guerrero-Romero JF, Rodriguez-Moran M, Bracho-Riquelme RL, Carrera-Gracia MA, Quintanar-Escorza MA: Eryptosis and oxidative damage in type 2 diabetic mellitus patients with chronic kidney disease. Mol Cell Biochem 2011;357:171-179.

106 Lang PA, Beringer O, Nicolay JP, Amon O, Kempe DS, Hermle T, Attanasio P, Akel A, Schafer R, Friedrich B, Risler T, Baur M, Olbricht CJ, Zimmerhackl LB, Zipfel PF, Wieder T, Lang F: Suicidal death of erythrocytes in recurrent hemolytic uremic syndrome. J Mol Med (Berl) 2006;84:378-388.

107 Nicolay JP, Schneider J, Niemoeller OM, Artunc F, Portero-Otin M, Haik G Jr., Thornalley PJ, Schleicher E, Wieder T, Lang F: Stimulation of suicidal erythrocyte death by methylglyoxal. Cell Physiol Biochem 2006;18:223-232.

108 Kempe DS, Akel A, Lang PA, Hermle T, Biswas R, Muresanu J, Friedrich B, Dreischer P, Wolz C, Schumacher U, Peschel A, Gotz F, Doring G, Wieder T, Gulbins E, Lang F: Suicidal erythrocyte death in sepsis. J Mol Med (Berl) 2007;85:273-281.

109 Lang PA, Schenck M, Nicolay JP, Becker JU, Kempe DS, Lupescu A, Koka S, Eisele K, Klarl BA, Rubben H, Schmid KW, Mann K, Hildenbrand S, Hefter H, Huber SM, Wieder T, Erhardt A, Haussinger D, Gulbins E, Lang F: Liver cell death and anemia in Wilson disease involve acid sphingomyelinase and ceramide. Nat Med 2007;13:164-170.

110 Rizvi N, Hawkins MJ, Eisenberg PD, Yocum RC, Reich SD, Ligand LWG: Placebo-controlled trial of bexarotene, a retinoid $\mathrm{x}$ receptor agonist, as maintenance therapy for patients treated with chemotherapy for advanced non-small-cell lung cancer. Clin Lung Cancer 2001;2:210-215. 


\section{Cellular Physiology Cell Physiol Biochem 2016;40:1239-1251 \begin{tabular}{ll|l} 
DOI: 10.1159/000453178 & $\begin{array}{l}\text { O 2016 The Author(s). Published by S. Karger AG, Basel } \\
\text { www.karger.com/cpb }\end{array}$
\end{tabular} \\ Bhuyan et al.: Bexarotene-Induced Eryptosis}

111 Wakelee HA, Middleton G, Dunlop D, Ramlau R, Leighl N, Hao D, Lopez-Anaya A, Zatloukal P, Jacobs CD: A phase I pharmacokinetic study of bexarotene with vinorelbine and cisplatin in patients with advanced nonsmall-cell lung cancer (NSCLC). Cancer Chemother Pharmacol 2012;69:815-824.

112 Harrison HE, Bunting H, Ordway NK, Albrink WS: The Pathogenesis of the Renal Injury Produced in the Dog by Hemoglobin or Methemoglobin. J Exp Med 1947;86:339-356.

113 Borst O, Abed M, Alesutan I, Towhid ST, Qadri SM, Foller M, Gawaz M, Lang F: Dynamic adhesion of eryptotic erythrocytes to endothelial cells via CXCL16/SR-PSOX. Am J Physiol Cell Physiol 2012;302:C644-C651.

114 Andrews DA, Low PS: Role of red blood cells in thrombosis. Curr Opin Hematol 1999;6:76-82.

115 Chung SM, Bae ON, Lim KM, Noh JY, Lee MY, Jung YS, Chung JH: Lysophosphatidic acid induces thrombogenic activity through phosphatidylserine exposure and procoagulant microvesicle generation in human erythrocytes. Arterioscler Thromb Vasc Biol 2007;27:414-421.

116 Zwaal RF, Comfurius P, Bevers EM: Surface exposure of phosphatidylserine in pathological cells. Cell Mol Life Sci 2005;62:971-988.

117 Closse C, Dachary-Prigent J, Boisseau MR: Phosphatidylserine-related adhesion of human erythrocytes to vascular endothelium. Br J Haematol 1999;107:300-302.

118 Gallagher PG, Chang SH, Rettig MP, Neely JE, Hillery CA, Smith BD, Low PS: Altered erythrocyte endothelial adherence and membrane phospholipid asymmetry in hereditary hydrocytosis. Blood 2003;101:46254627.

119 Pandolfi A, Di Pietro N, Sirolli V, Giardinelli A, Di Silvestre S, Amoroso L, Di Tomo P, Capani F, Consoli A, Bonomini M: Mechanisms of uremic erythrocyte-induced adhesion of human monocytes to cultured endothelial cells. J Cell Physiol 2007;213:699-709.

120 Wood BL, Gibson DF, Tait JF: Increased erythrocyte phosphatidylserine exposure in sickle cell disease: flowcytometric measurement and clinical associations. Blood 1996;88:1873-1880. 